\title{
DEGRADASI MINYAK MENTAH DAN SOLAR OLEH KONSORSIUM MIKROBA ASAL PERTAMBANGAN MINYAK CEPU
}

\author{
Joko Prayitno ${ }^{1}$, Amalia Mahmudah², Esi Lisyastuti ${ }^{1}$ \\ (Diterima tgl : 1 \\ Disetujui tgl : \\ ...)
}

\begin{abstract}
The aim of this research was to obtain oil-degrading microbes from Cepu mining area and to investigate the best combination of microbial consortium to degrade crude and diesel oil. Two yeast isolates were obtained out of ten isolates from Cepu samples. Four best isolates (C7, C6, C4 an C3) were then selected and used for consortium experiments. All consortia either grown in crude or diesel oil showed increased in absorbance values (as the indication of oil degradation) and increased in cell populations at day three. However, $\mathrm{pH}$ of the medium decreased from 6.5 at day zero to 2.9-3.5 at day three. After day three, the absorbance values, cell populations and pHs tend to flat or slightly reduced. The best combination of microbial consortium was K3, containing C7, C6 and C4 isolates. This consortium was able to degrade 49-50\% of crude or diesel oil for 12 day.
\end{abstract}

Keywords: Lignocelluloce, bioethanol, hydrolysis, fermentation

ABSTRAK

\section{PENDAHULUAN}

Pencemaran minyak bumi di lahan dan perairan menimbulkan masalah serius bagi lingkungan sekitarnya. Pencemaran minyak bumi dapat berasal dari proses penambangan di darat dan lepas pantai, limbah hasil pengolahan, kecelakan kapal pengangkut minyak bumi, atau dari sisa pencucian minyak dari kapal. Kasus pencemaran minyak bumi akibat tumpahan minyak telah banyak diketahui(1,2,3). Minyak bumi terdiri dari campuran kompleks senyawa-senyawa hidrokarbon alifatik dan aromatik, aspal, dan resin. Hasil distilasi minyak bumi adalah senyawa-senyawa hidrokarbon dengan jumlah rantai karbon yang bervariasi seperti bensin, kerosen, solar, minyak berat, oli dan residu(4). Penanggulangan pencemaran minyak bumi dapat dilakukan dengan teknik kimia, fisika maupun biologi. Pendekatan biologis untuk menanggulangi pencemaran minyak atau dikenal dengan istilah bioremediasi banyak menjadi pilihan karena lebih ramah lingkungan dan dapat mendegradasi senyawa

${ }^{1}$ Balai Teknologi Lingkungan, Badan Pengkajian dan Penerapan Teknologi, Gd. 412 Puspiptek Serpong, Tangerang 15314. telp. 0217560919, Fax 021-7563116, Email: joko2812@yahoo.co.id

${ }^{2}$ Fakultas Biologi, Universitas Jenderal Soedirman, Jl. HR. Boenyamin No. 708, Purwokerto. 
polutan menjadi bentuk yang sederhana dan tidak berbahaya. Teknik bioremediasi menggunakan agensia mikroba sangat potensial dikembangkan dan diaplikasikan di Indonesia karena karena lebih sederhana dan murah serta sumber hayati mikroba yang melimpah.

Mikroorganisme yang berperan utama dalam mendegradasi senyawa pencemar minyak adalah dari jenis bakteri dan jamur (yeast) tertentu yang tumbuh di alam(5,6,7). Karena tidak semua mikroba dapat mendegradasi minyak bumi, maka banyak upaya dilakukan untuk mengisolasinya terutama dari kawasan yang tercemar minyak. Di daerah tersebut, beberapa jenis mikroba setempat tumbuh dan beradaptasi dengan lingkungan yang tercemar. Mikroba yang diisolasi dari tempat yang tercemar minyak memiliki kemampuan tinggi dalam mendegradasi minyak atau polutan. Seringkali suatu jenis mikroba hanya mampu mendegradasi senyawa hidrokarbon pada kisaran berat molekul tertentu. Karena itu kombinasi mikroba yang tepat dalam suatu kultur campuran akan lebih menjamin keberhasilan proses degradasi senyawa pencemar minyak. Dalam suatu konsorsium, beberapa jenis mikroba bekerja secara bersamaan untuk mendegradasi senyawa pencemar minyak sesuai dengan spesifitas substrat yang dimiliki.

Tujuan dari penelitian ini adalah mendapatkan isolat-isolat potensial yang mampu mendegradasi senyawa pencemar minyak serta kombinasi mikroba yang cocok digunakan dalam kultur konsorsium. Isolat-isolat tersebut diperoleh dari tanah yang terkena tumpahan minyak di daerah tambang minyak Cepu.

\section{METODOLOGI}

Isolat dan isolasi. Isolat mikroba diisolasi dari tanah yang terkena tumpahan minyak di sekitar lokasi sumur minyak Cepu, Kabupaten Blora, Jawa Tengah. Sampel tanah $5 \mathrm{~g}$ dimasukkan ke dalam 100 ml medium Bushnell dan Hass (BH) yang berisi $2 \%(\mathrm{v} / \mathrm{v})$ minyak mentah atau solar steril. Kultur dikocok di atas shaker selama 7 hari pada suhu ruang, kemudian dilakukan subkultur sebanyak dua kali. Mikroba yang tumbuh diisolasi di atas media Nutrient Agar (NA) pada suhu ruang. Isolat-isolat murni yang didapat kemudian dikarakterisasi dengan melihat morfologi koloni, morfologi sel, reaksi pewarnaan Gram dan motilitas sel.

Uji Degradasi. Tiap-tiap isolat ditumbuhkan dalam medium Nutrient Broth (NB) selama 24 jam pada suhu ruang di atas shaker. Biomassa sel dipanen dengan menggunakan sentrifuse pada kecepatan 3500 rpm selama 15 menit. Pelet yang diperoleh kemudian disuspensikan dalam medium BH. Konsentrasi sel dalam larutan diukur dengan menggunakan spektrofotometer pada panjang gelombang 600 $\mathrm{nm}$. Suspensi mikroba $(\mathrm{OD} 600=1.00)$ dipipet sebanyak $1 \mathrm{ml}$ ke dalam $100 \mathrm{ml}$ medium $\mathrm{BH}$ yang berisi $2 \%(\mathrm{v} / \mathrm{v})$ minyak mentah atau solar. Kultur diinkubasi di atas shaker selama 9 hari pada suhu ruang. Tingkat degradasi minyak dalam larutan ditentukan dengan mengukur tingkat absorbansi larutan pada panjang gelombang $600 \mathrm{~nm}$ menggunakan spektrofotometer. Sebelum diukur, $4 \mathrm{ml}$ larutan kultur disentrifuse terlebih dahulu pada kecepatan 3500 rpm selama 15 menit untuk memisahkan larutan dari sel-sel mikroba. Tingkat degradasi minyak dalam larutan, populasi sel dan $\mathrm{pH}$ medium ditetapkan pada 
hari ke-3, 6 dan 9. Sebagai pembanding, diukur pula nilai absorbansi kontrol yaitu kultur berisi medium cair yang ditambahkan minyak mentah atau solar.

Uji kemampuan konsorsium dalam mendegradasi minyak dilakukan dengan mencampurkan tiga isolat dari empat isolat terbaik. Masing-masing isolat tunggal ditumbuhkan dalam media NB selama 24 jam pada suhu ruang, kemudian OD masing-masing kultur diset menjadi 1.0 setelah sentrifugasi. Setelah dicampur dengan perbandingan yang sama $(\mathrm{v} / \mathrm{v} / \mathrm{v}), 1 \mathrm{ml}$ konsorsium $(\mathrm{OD}=1.0)$ dipindahkan ke $100 \mathrm{ml}$ media $\mathrm{BH}$ yag berisi $2 \%(\mathrm{v} / \mathrm{v})$ minyak mentah atau solar. Kultur diinkubasi di atas shaker selama 12 hari.

Pengukuran Kadar Minyak Sisa. Kadar minyak yang tidak terdegradasi oleh mikroba dalam kultur ditetapkan dengan metode gravimetri menggunakan $25 \mathrm{ml}$ pelarut hexan. Sebelum diekstraksi, kultur disentrifuge pada kecepatan 3500 rpm selama 15 menit untuk memisahkan larutan dari sel-sel mikroba. Pelarut hexan yang berisi minyak dalam labu destilasi diuapkan dalam penangas air pada suhu $70-85^{\circ} \mathrm{C}$. Labu destilasi yang berisi minyak sisa dikeringkan dalam oven selama 2 jam pada suhu $80^{\circ} \mathrm{C}$.

\section{HASIL DAN PEMBAHASAN}

\section{Karakteristik isolat}

Dari sampel tanah di pertambangan minyak Cepu berhasil diisolasi sepuluh isolat yang berpotensi mendegradasi senyawa minyak. Dari kesepuluh isolat tersebut, enam isolat berasal dari kultur yang mengandung minyak mentah, yaitu isolat $\mathrm{C} 1, \mathrm{C} 2, \mathrm{C} 6, \mathrm{C} 8, \mathrm{C} 9$ dan $\mathrm{C} 10$. Sedangkan empat isolat lainnya berasal dari kultur yang mengandung solar, yaitu isolat C3, C4, C5 dan C7. Karakterisitik morfologi sel dari isolat-isolat yang didapat menunjukkan bahwa delapan isolat adalah bakteri, sedangkan dua isolat lain yaitu C6 dan C7 adalah yeast (Tabel 1). Sebagian besar morfologi koloni isolat berbentuk bulat, dan hanya satu isolat yang memiliki bentuk koloni tak beraturan, yaitu C9. Ketika dilihat di bawah mikroskop, morfologi sel dari isolatisolat yang didapat tersebut berbentuk batang dan kokus (Tabel 1).

Tabel 1: Morfologi koloni dan karakterisitik sel dari isolat-isolat yang didapat dari sampel tanah Cepu

\begin{tabular}{|c|c|c|c|c|c|c|c|}
\hline \multirow{2}{*}{ Isolat } & \multirow{2}{*}{$\begin{array}{c}\text { Jenis } \\
\text { Mikroba }\end{array}$} & \multicolumn{3}{|c|}{ Morfologi Koloni } & \multicolumn{3}{|c|}{ Karakterisitik Sel } \\
\hline & & bentuk & tepi & warna & bentuk & Reaksi Gram & Motilitas \\
\hline $\mathrm{C} 1$ & bakteri & bulat & halus & $\begin{array}{c}\text { Coklat } \\
\text { kemerahan }\end{array}$ & kokus & negatif & motil \\
\hline $\mathrm{C} 2$ & bakteri & bulat & halus & $\begin{array}{c}\text { Putih } \\
\text { kekuningan }\end{array}$ & batang & positif & motil \\
\hline $\mathrm{C} 3$ & bakteri & bulat & bercuping & Coklat bening & kokus & negatif & motil \\
\hline $\mathrm{C} 4$ & bakteri & bulat & halus & Putih krem & batang & positif & motil \\
\hline C5 & bakteri & bulat & halus & $\begin{array}{c}\text { Coklat } \\
\text { kehijauan }\end{array}$ & kokus & positif & motil \\
\hline $\mathrm{C} 6$ & Yeast & bulat & halus & Putih kusam & Sel bertunas & - & Non motil \\
\hline C7 & yeast & bulat & bercuping & Putih kusam & Sel bertunas & - & Non motil \\
\hline C8 & bakteri & bulat & $\begin{array}{c}\text { Tak } \\
\text { beraturan }\end{array}$ & Coklat krem & kokus & positif & motil \\
\hline $\mathrm{C} 9$ & bakteri & $\begin{array}{c}\text { Tak } \\
\text { beraturan }\end{array}$ & bercuping & coklat & batang & negatif & motil \\
\hline $\mathrm{C} 10$ & bakteri & bulat & halus & Putih krem & kokus & negatif & motil \\
\hline
\end{tabular}


a

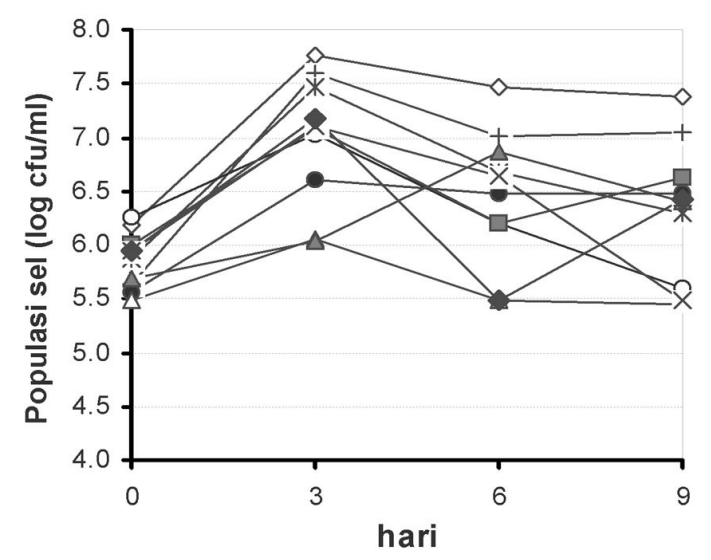

b

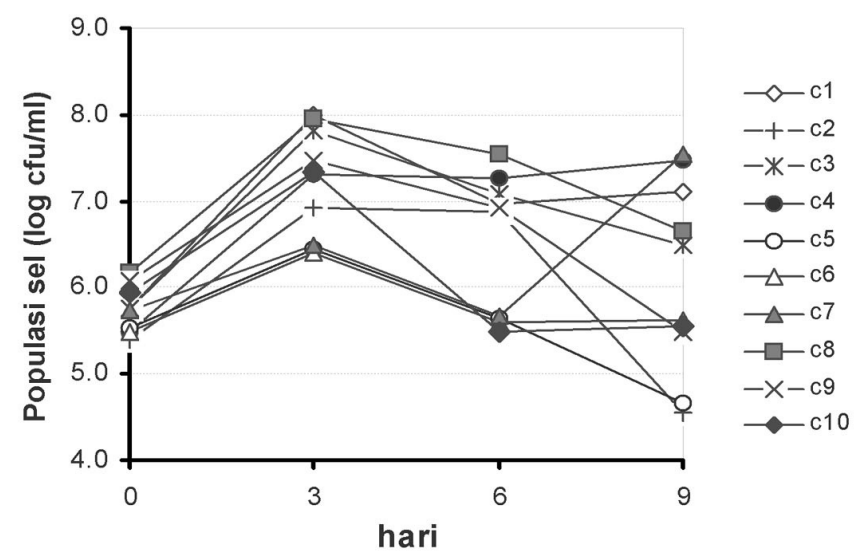

Gambar 1: Tingkat absorbansi minyak terlarut dari masing-masing isolat dalam kultur yang berisi sumber karbon tertentu. (a) minyak mentah, (b) solar.

\section{Seleksi isolat tunggal}

Untuk melihat kemampuan degradasi masingmasing isolat, setiap isolat ditumbuhkan dalam media $\mathrm{BH}$ yang berisi minyak mentah atau solar. Kemampuan degradasi ditentukan secara tidak langsung dengan mengukur tingkat kekeruhan media akibat minyak yang terlarut. Hasil percobaan menunjukkan bahwa terjadi peningkatan kekeruhan media serta terbentuknya butiran-butiran minyak yang terdispersi dalam air selama percobaan berlangsung. Peningkatan absorbansi minyak terlarut berlangsung cepat pada hari ke-3 dan berlanjut hingga hari ke-9, baik pada kultur berisi minyak mentah ataupun solar (Gambar 1a dan 1b). Kontrol (tanpa penambahan mikroba) tidak menunjukan adanya perubahan kekeruhan media dan dispersi minyak (Gambar 1a dan 1b). Hal tersebut mengindikasikan bahwa seluruh isolat yang dicoba mampu tumbuh dan menggunakan minyak mentah atau solar sebagai sumber karbon untuk proses metabolisme sel. Dari sepuluh isolat yang dicoba, nilai absorbansi tertinggi dijumpai pada empat isolat yaitu $\mathrm{C} 7, \mathrm{C} 6, \mathrm{C} 4$ dan $\mathrm{C} 3$, dengan nilai absorbansi berkisar antara 0.20-
0.27 (Gambar 1). Tingkat absorbansi minyak yang tinggi dari keempat isolat tersebut dijumpai baik pada perlakuan minyak mentah maupun solar.

Adanya aktifitas metabolisme mikroba juga ditandai dengan penurunan $\mathrm{pH}$ media dari 6.6 pada awal percobaan menjadi 3.8-5.5 pada hari ke-3, dan menjadi 2.8-4.0 pada hari ke-9, baik dalam kultur dengan minyak mentah maupun dengan solar (data tidak ditampilkan). Hasil ini menunjukkan bahwa peningkatan absorbansi minyak terlarut yang cepat dan penurunan $\mathrm{pH}$ media yang drastis terjadi pada tiga hari pertama kultur.

Populasi mikroba dalam kultur meningkat pesat pada hari ke-3 pada perlakuan minyak mentah maupun solar. Populasi tertinggi pada perlakuan minyak mentah dijumpai pada isolat $\mathrm{C} 1$, yaitu sebesar $7.4 \log \mathrm{cfu} / \mathrm{ml}$ pada hari ke-9 (Gambar 2a). Pada perlakuan solar, populasi tertinggi dijumpai pada isolat $\mathrm{C} 4$, yaitu 7.5 $\log \mathrm{cfu} / \mathrm{ml}$ pada hari ke-9 (Gambar 2b). Setelah hari ke-3, populasi sel baik pada perlakukan minyak mentah ataupun solar cenderung tetap ataupun menurun. 
a

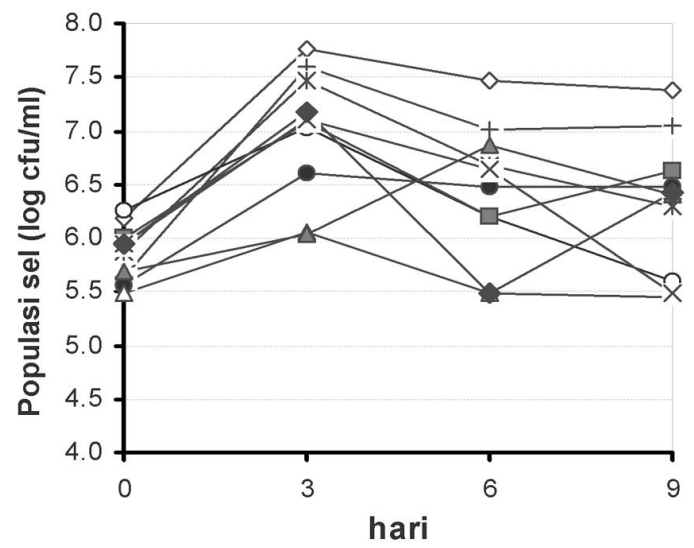

b

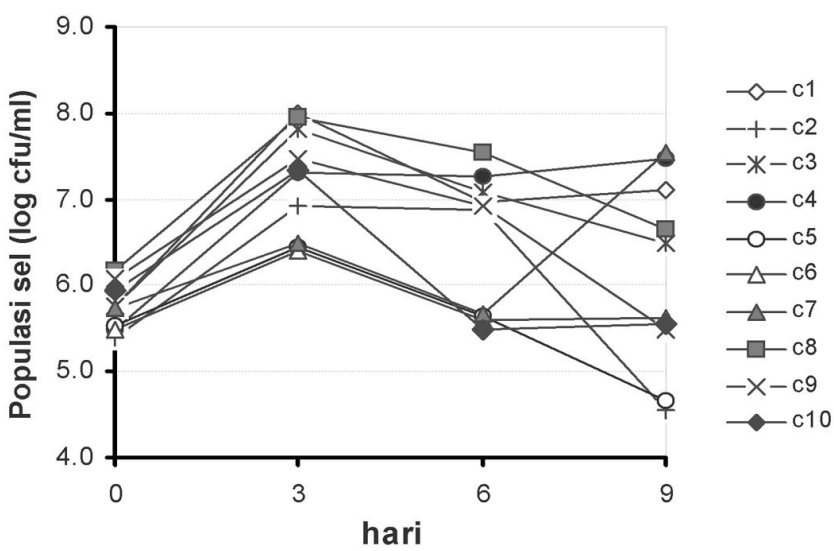

Gambar 2: Populasi sel dari masing-masing isolat dalam kultur yang berisi sumber karbon tertentu. (a) minyak mentah, (b) solar.

\section{Uji degradasi konsorsium mikroba}

Empat isolat yaitu C7, C6, C4 dan C3 memiliki nilai absorbansi minyak terlarut yang paling tinggi diantara sepuluh isolat yang diuji. Keempat isolat tersebut selanjutnya dipilih dan dikombinasikan untuk mendapatkan formulasi konsorsium mikroba yang optimum dalam mendegradasi minyak. Ada tiga jenis konsorsium yang diuji, dan tiap konsorsium terdiri atas tiga mikroba unggul. Ketiga konsorsium tersebut yaitu isolat $\mathrm{C} 7, \mathrm{C} 4$ dan $\mathrm{C} 3(\mathrm{~K} 1)$, isolat $\mathrm{C} 7, \mathrm{C} 6$ dan $\mathrm{C} 3(\mathrm{~K} 2)$ dan isolat C7, C6 dan C4 (K3).

Nilai absorbansi minyak terlarut pada perlakuan kontrol (K0, tanpa penambahan konsorsium) pada hari ke-9 tidak mengalami peningkatan dibanding dengan hari ke-0 (Gambar 3a-b). Seperti halnya pada uji isolat tunggal, nilai absorbansi minyak terlarut dalam kultur konsorsium meningkat di hari ke-3. Namun pola peningkatan nilai absorbansi hingga hari ke-9 berbeda antara perlakuan minyak mentah dengan solar. Pada perlakuan minyak mentah, nilai absorbansi meningkat hingga hari ke-6, setelah itu hanya $\mathrm{K} 3$ yang masih menunjukkan peningkatan. Nilai absorbansi paling tinggi dijumpai pada K2 di hari ke-6, yaitu sebesar
0.36 (Gambar 3a). Pada perlakuan solar, nilai absorbansi meningkat di hari ke-3, setelah itu nilai absorbansi tidak mengalami perubahan (Gambar 3b). Nilai absorbansi tertinggi di hari ke-3 pada perlakuan solar dijumpai pada K1 yaitu sebesar 0.26 .

Populasi mikroba dalam kultur yang tidak diberi minyak tidak mengalami perubahan yang berarti pada hari ke-9 dibanding dengan hari ke-0 (Gambar 4a). Sedangkan populasi mikroba pada ketiga jenis konsorsium yang dicoba mengalami peningkatan di hari ke-3, namun setelah itu tidak mengalami perubahan berarti hingga hari ke-9 (Gambar 4b-c). Hal ini terlihat baik pada perlakuan minyak mentah maupun solar.

pH kultur dari ketiga konsorsium yang diberi perlakuan minyak mentah dan solar tidak mengalami perubahan di hari ke-9 dibanding dengan hari ke-0, yaitu sebesar 6.5 (Gambar 5a). Berlawanan dengan peningkatan nilai absorbansi minyak terlarut yang meningkat di hari ke-3, nilai $\mathrm{pH}$ kultur menurun di hari ke-3, dan tidak mengalami perubahan berarti hingga hari ke-9, terutama pada perlakuan solar (Gambar 5b-c). pH media pada hari 
a

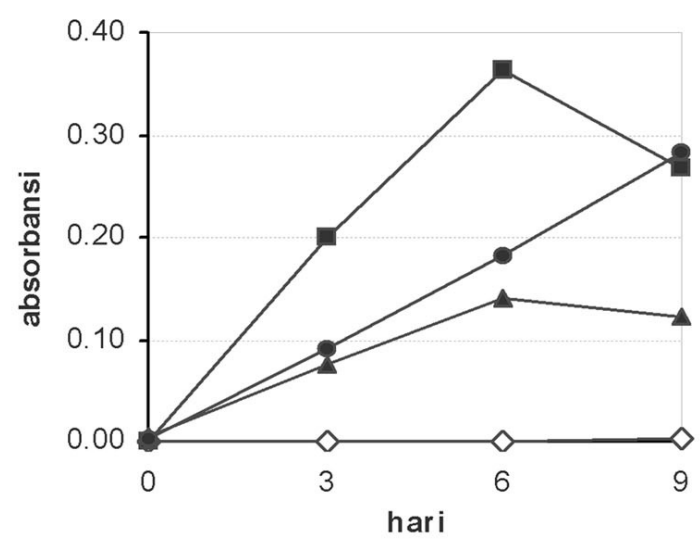

b

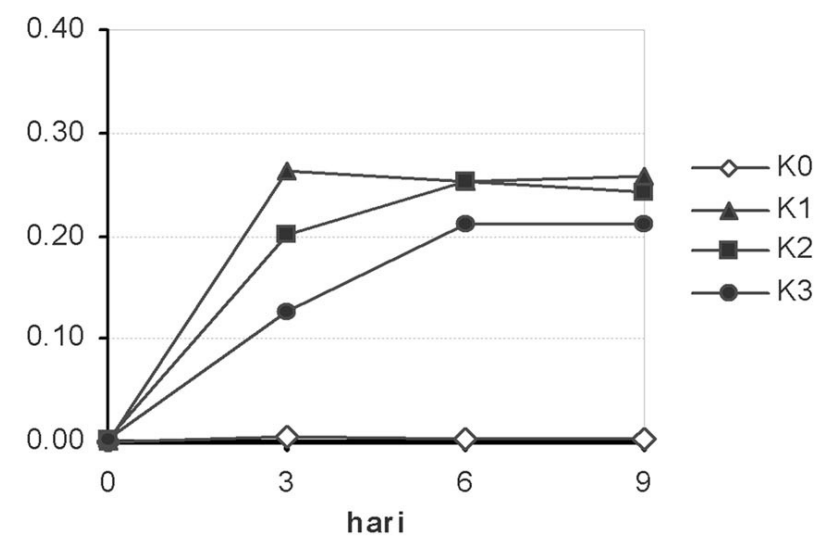

Gambar 3: Tingkat absorbansi minyak terlarut oleh konsorsium dalam kultur yang berisi sumber karbon tertentu. (a) minyak mentah, (b) solar.
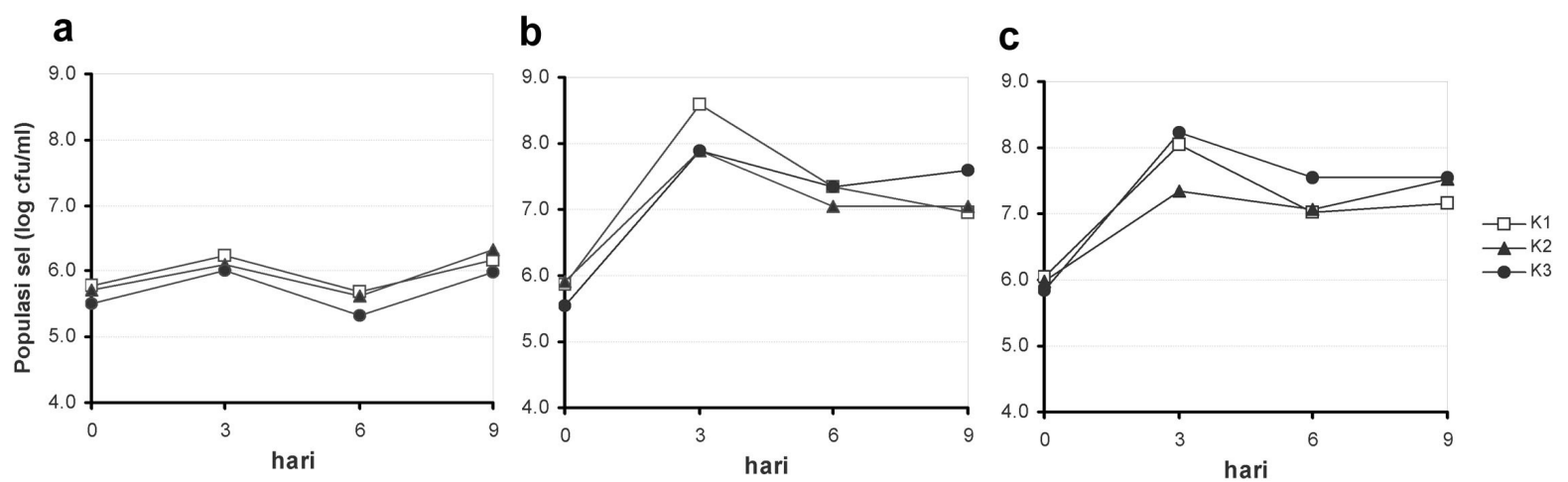

Gambar 4: Populasi sel dari masing-masing konsorsium dalam kultur yang berisi sumber karbon tertentu. (a) tanpa penambahan minyak (b) minyak mentah, (c) solar.
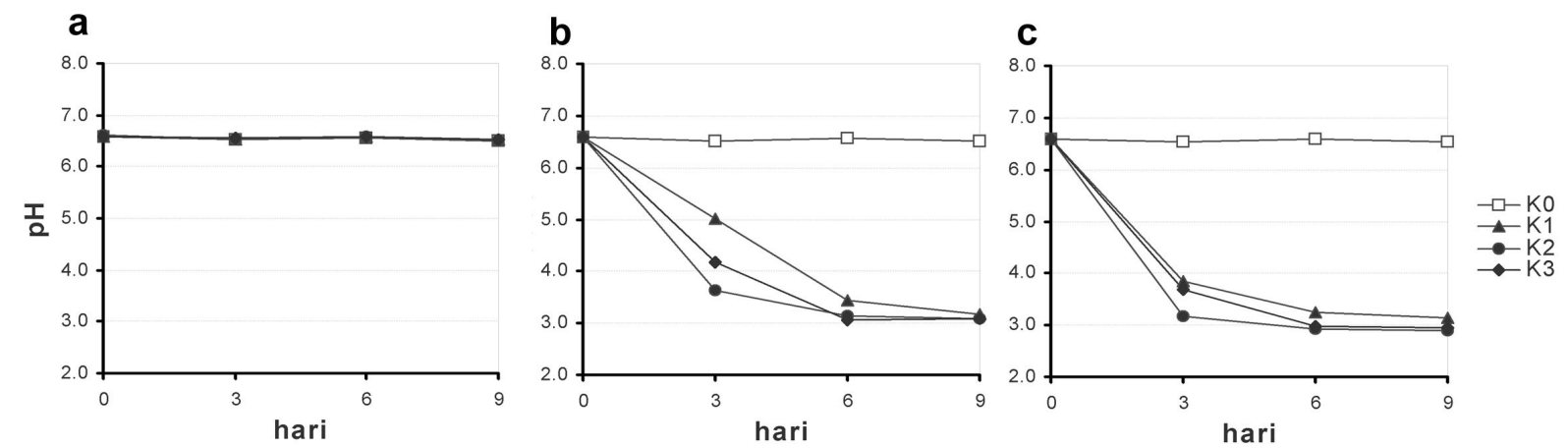

Gambar 5: pH medium dari kultur konsorsium yang berisi sumber karbon tertentu. (a) tanpa penambahan minyak, (b) minyak mentah, (c) solar.

ke-9 pada perlakuan minyak mentah dan solar berkisar antara 2.9-3.1.

Untuk melihat jumlah minyak yang didegradasi oleh masing-masing konsorsium mikroba, berat minyak yang diperoleh setelah ekstraksi diukur dengan metode gravimetri. Persentase minyak yang didegradasi oleh konsorsium mikroba pada hari ke-12 berkisar antara 38.6$50.0 \%$ (Tabel 2). Persentase minyak yang terdegradasi paling tinggi dijumpai pada $\mathrm{K} 3$, yaitu $49.4 \%$ pada minyak mentah dan $40.0 \%$ pada solar. 
Tabel 2: Persentase minyak yang terdegradasi oleh konsorsium mikroba asal Cepu pada hari ke-12 inkubasi.

Dari percobaan ini berhasil diperoleh sepuluh isolat mikroba pendegradasi minyak yang terdiri dari bakteri dan yeast. Kemampuan yeast dalam mendegradasi senyawa minyak bumi telah banyak dilaporkan $(5,7)$. Hasil degradasi minyak bumi tersebut menghasilkan asamasam organik yang menyebabkan terjadinya penurunan $\mathrm{pH}$ medium(5,8). Dalam percobaan ini, $\mathrm{pH}$ medium yang turun hingga 3.0 kemungkinan juga disebabkan oleh akumulasi asam-asam organik yang terbentuk selama proses metabolisme minyak mentah atau solar. Selain dapat mendegradasi senyawa minyak menjadi senyawa lebih sederhana, bakteri dan yeast tertentu juga dapat menghasilkan senyawa bioemulsi yang dapat menurunkan tegangan permukaan antara minyak dan air(9). Namun sejauh mana peranan bioemulsi dalam proses degradasi minyak oleh mikroba yang diuji dalam percobaan ini belum diketahui dan perlu dikaji lebih jauh.

Konsorsium mikroba yang diuji dalam percobaan ini dapat mendegradasi minyak hingga 50\% di hari ke-12. Hasil percobaan ini juga menunjukkan bahwa aktifitas degradasi minyak yang tinggi oleh mikroba yang diuji terjadi selama tiga hari pertama. Selain itu, peningkatan populasi sel paling banyak terjadi hingga hari ke-3. Oleh karena itu perlu dilakukan penelitian lebih lanjut faktor-faktor yang menyebabkan terjadinya penurunan aktifitas tersebut, diantaranya kondisi nutrisi, $\mathrm{pH}$ dan pembentukan senyawa intermediet yang bersifat menghambat pertumbuhan/ metabolisme sel. 


\section{KESIMPULAN}

1. Sepuluh isolat mikroba pendegradasi minyak diisolasi dari sampel tanah pertambangan minyak Cepu, dua diantaranya adalah isolat yeast.

2. Dari sepuluh isolat, isolat C7, C6, C4 dan C3 memiliki tingkat degradasi minyak terbaik.

3. Konsorsium mikroba yang terdiri dari isolat C7, C6 dan C4 memiliki persentasi minyak yang terdegradasi paling tinggi, baik pada perlakuan minyak mentah ataupun solar, yaitu sebesar 50\% pada hari ke-12.

\section{DAFTAR PUSTAKA}

(1) Anonim. 1992. Oil Spill Case History 1967-1991, Summaries of Significant US and International Spills. NOAA/ Hazardous Materials Response and Assenssment Division, Seattle, Washington. $224 \mathrm{p}$.

(2)http://www.antaranews.com/en/ news/1286083223/pertaminainvestigating-oil-spill-in-cilacap. Diakses tanggal 4 Oktober 2010.

(3)http://www.consumerenergyreport. com/2010/06/20/internal-documentbp-estimates-spill-rate-up-to-100000bpd/. Diakses tanggal 4 Oktober 2010.

(4) Zhendi W., Hollebone B.P, Fingas M., Fieldhouse B., Sigouin L., Landriault M., Smith P., Noonan J., and Thouin
G., 2003, Characteristics of Spilled Oils, Fuels, and Petroleum Products, 1. Composition and Properties of Selected Oils, National Exposure Research Laboratory,United States Environmental Protection Agency, 286p.

(5) Van Hamme J.D., Sing A. and Ward O.W., 2003, Recent advances in petroleum microbiology, Microbiol Molec Biol Rev, 67, 503-549.

(6) Atlas R.M., and Cerniglia C.E. 1995, Bioremediation of petroleum pollutants: diversity and environmental aspects of hydrocarbon biodegradation, BioScience, 45, 332-338.

(7) Nurhariyati T., Ni'matuzahroh dan Surtiningsih T. 2006, Biodegradasi minyak oleh Rohodotorula dan Candida hasil isolasi dari pelabuhan Tanjung Perak Surabaya, Berk Penel Hayati, 12, 27-31.

(8) de Cássia Miranda R., de Souza C.S., de Barros Gomes E., Roberta, Lovaglio B., Lopes C.E. and de Queiroz Sousa MFV, 2007, Biodegradation of diesel oil by yeasts isolated from the vicinity of suape port in the State of Pernambuco -Brazil, Brazilian Arch Biol Tech, 50, 147-152.

(9) Duvnjak Z., and Kosaric N., 1987, Deemulsification of petroelum water-inoil emulsions by selected bacterial and yeast cells. Biotechnol Lett., 9, 39-42. 